\title{
CTAG2 Antibody
}

National Cancer Institute

\section{Source}

National Cancer Institute. CTAG2 Antibody. NCI Thesaurus. Code C111808.

Any immunog lobulin that recognizes cancer/testis antigen 2 . 